
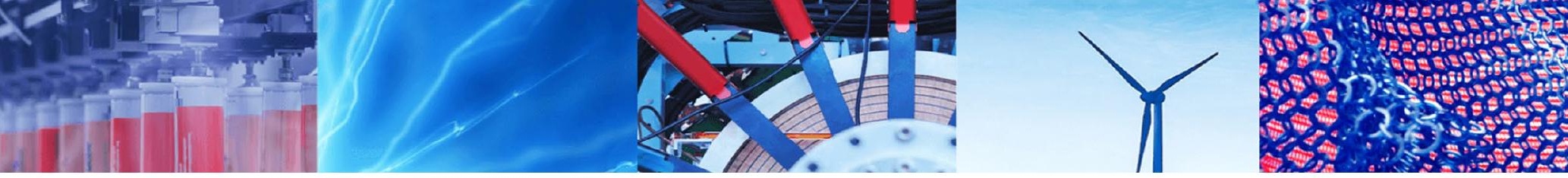

Research Article

\title{
Heavy metal removal from industrial effluent using bio-sorbent blends
}

\author{
I. Sreedhar ${ }^{1}\left[\right.$ ] N. Saketharam Reddy ${ }^{1}$
}

(c) Springer Nature Switzerland AG 2019

\begin{abstract}
There is extensive literature on the use of adsorbents derived from waste to treat industrial effluents containing heavy metal ions. However, there is limited information on the use of adsorbent blends. This is applicable for treating effluents which contain a number of heavy metals, so any one single adsorbent may not be suitable for achieving high percent removal of all ions. The present work employs adsorbent blends to treat an electrochemical effluent in batch mode. This work aims to provide valuable insights on the interaction of heavy metals with the adsorbents in blends. Effluent from an electrochemical industry was treated with blends of calcium bentonite, fly ash and wheat bran in different compositions to remove heavy metal ions $(\mathrm{Fe}, \mathrm{Ni}, \mathrm{Cu}, \mathrm{As}, \mathrm{Zn}, \mathrm{Cd}$ ) from an aqueous effluent solution. The optimal set of conditions identified were $\mathrm{pH}$, 5-7; contact time, 60-90 min; agitation speed of $200 \mathrm{rpm}$; adsorbent dosage of $1 \mathrm{~g} / 50 \mathrm{~mL}$; and particle size of $150-300 \mu$. Metal ions arsenic, zinc and cadmium were completely removed. The percentage removal of $(\mathrm{Fe}, \mathrm{Ni}$, $\mathrm{Cu})$ metal ions was in the order $\mathrm{Fe}(\mathrm{II})(96.73 \%)>\mathrm{Ni}(\mathrm{II})(74.03 \%)>\mathrm{Cu}(\mathrm{II})(70.70 \%)$ at optimum conditions in a short equilibrium time of $90 \mathrm{~min}$. Batch experiments were conducted to determine the factors such as adsorbent composition, temperature, $\mathrm{pH}$, agitation speed, dosage, contact time and particle size affecting adsorption, and all these parameters were found to strongly influence the adsorption. Experimental data were analyzed for Langmuir and Freundlich isotherms. Langmuir isotherm shows the maximum adsorption capacities were in order $\mathrm{Fe}(\mathrm{II}) 146.1 \mathrm{mg} / \mathrm{g}>\mathrm{Ni}$ (II) $115.9 \mathrm{mg} / \mathrm{g}>\mathrm{Cu}$ (II) $74.5 \mathrm{mg} / \mathrm{g}$. Freundlich parameter ' $n$ ' was found to be greater than 1 which showed that the adsorption is feasible for all three metals. Freundlich isotherm fit the data comparatively better, but neither of the two isotherms satisfactorily explained the adsorption, which indicated heterogeneity of adsorption. Kinetic studies were performed and analyzed for pseudo-first- and pseudo-second-order kinetics and the Weber-Morris intraparticle diffusion model. The adsorption data fit accurately to pseudo-second-order kinetic model with coefficient of correlation values greater than 0.99 for all three heavy metals. The kinetic constants were found to be $8.49 * 10^{-3}, 5.82 * 10^{-3}, 5.27 * 10^{-3} \frac{\mathrm{g}}{\mathrm{mg} \mathrm{min}}$ for $\mathrm{Fe}(\mathrm{II}), \mathrm{Ni}(\mathrm{II})$ and $\mathrm{Cu}(\mathrm{II})$, respectively. From the intraparticle diffusion model, it was inferred that there were different rate-limiting steps during the duration of the adsorption process, including intraparticle diffusion and boundary layer diffusion.
\end{abstract}

Keywords Heavy metal adsorption · Process standardization · Adsorption kinetics · Langmuir isotherm · Freundlich isotherm · Intraparticle diffusion · Batch reaction

\section{Introduction}

Water is one of the most essential elements for life on earth. But due to human activities, fresh water is getting polluted at an alarming rate. Rigorous studies were carried out all around the globe to study treatment of different contaminants in industrial effluents. Heavy metals are one of the most toxic pollutants. Some well-known toxic metallic elements are arsenic, iron, chromium, cadmium, lead, nickel, copper, zinc and mercury. Heavy metals are toxic and non-biodegradable and can bio-accumulate in living cells [1]. Heavy metals not only damage human health

I. Sreedhar, isreedhar2001@yahoo.co.in | 'Department of Chemical Engineering, BITS Pilani Hyderabad Campus, Hyderabad, India.

SN Applied Sciences (2019) 1:1021 | https://doi.org/10.1007/s42452-019-1057-4

Received: 4 April 2019 / Accepted: 7 August 2019 / Published online: 12 August 2019 
but also affect the environment and marine ecosystems and pose a significant health threat to aquatic life-most common being the damage of the gill of fish $[2,3]$. Various methods to remove heavy metals exist such as chemical precipitation [4], membrane filtration [5], electrodialysis [6], photocatalysis [7], electrocoagulation [8] and adsorption [9]. Adsorption has been an important area of interest in the recent years, with majority latest research focused on identifying low-cost adsorbents [9]. Research work is also being done to synthesize new adsorbents with some recent advances in novel adsorbents which include using activated carbon synthesized from peanut shell [10], alizarin red-S-loaded amberlite IRA-400 anion exchange resin [11], starch $/ \mathrm{SnO}_{2}$ nanocomposite [12], $\mathrm{Fe}_{3} \mathrm{O}_{4}$ nanocomposites [13], MOF (metal organic framework)-based composites [14, 15], nickel ferrite bearing nitrogen-doped mesoporous carbon ( $\mathrm{NiFe}_{2} \mathrm{O}_{4}-\mathrm{NC}$ ) [16], nanocomposite cation exchanger sodium dodecyl sulfate acrylamide $\mathrm{Zr}$ (IV) selenite (SDS-AZS) [17] for removing toxic heavy metals. Such adsorbents are specially tailored to give them favorable properties like high adsorption capacity, regeneration capability, high surface area, mechanical and thermal stability $[18,19]$. Currently, activated charcoal is the adsorbent of choice, but high costs are a concern [20]. Therefore, cheap bio-derived materials of renewable sources are suitable alternatives [21, 22]. Some of the common bio-adsorbents, bio-derived and industrial waste products used as adsorbents are bacteria [23], fungi [24], algae [25], tea waste [26], rice bran [27], egg shell [28], fuller's earth [29], fly ash [30] among others. The present study aims to use such low-cost adsorbents for treating a wide variety of heavy metals simultaneously. As we show in this work, these adsorbents are typically selective toward certain heavy metals and are not suitable for treating effluents with a number of different heavy metal ions. For such cases, it is proposed that a mixture of adsorbents be used to treat the effluent, so that all the ions may be removed. In this study, six adsorbents were used for initial screening, i.e., rice bran, wheat bran, sweet lime peel, egg shells, fly ash and Ca bentonite. At specified conditions, these adsorbents were employed to treat battery manufacturing effluent by batch adsorption. Among these adsorbents, three adsorbents, viz. wheat bran, fly ash and Ca bentonite, were selected based on their performance in the metal removal for further rigorous studies at the second level. Wheat bran is the shell of the wheat seed and is removed when processing wheat to flour [31]. Coal fly ash is an inorganic residue which is produced by combustion of coal and considered as an industrial waste and used as a filler in different applications [32, 33]. It has potential use in treating wastewater due to its chemical composition, i.e., silica, alumina, ferric oxide, magnesium oxide and calcium oxide, and its physical properties like surface area, particle size and porosity [34]. Ca bentonite is clay which is in abundance in earth's crust. In the present study, investigations were conducted in three phases-initial screening of adsorbents from six suitable candidates, rigorous standardization and characterization (FTIR and BET) studies using selected sorbents and their blends vis-à-vis various critical process parameters like sorbent composition, contact time, dosage, agitation speed, particle size, $\mathrm{pH}$ and temperature to identify the optimal set of parameters to maximize the metal removal from the effluent and then finally fitting the experimental data to various adsorption isotherms like Langmuir and Freundlich and then estimating the kinetic parameters like reaction order, rate constant by proposing various kinetic models and fitting the experimental data to each to find the most suitable model. The role of intraparticle diffusion on the adsorption kinetics was studied by fitting the kinetic data to the Weber and Morris model. Thermodynamic parameters relating to adsorption of heavy metals were also calculated. It should be mentioned here that adsorbent blends are different from adsorbent composites. The adsorbent 'blending' in this work refers to simple mixing of the adsorbents in required weight ratio, while adsorbent 'composites' are made with the intent to improve the physical properties (thermal, mechanical, etc.) of the component adsorbents. Preparing these composites typically involve chemical reactions like cross-linking and surface treatment [35].

\section{Materials and method}

\subsection{Materials}

Materials used for the experiments are of analytical grades. Effluent was obtained from an electrochemical industry, and the adsorbent used for the experiments is sweet lime peel, egg shells, wheat bran, rice bran, fly ash and calcium bentonite. All the adsorbents were procured locally from Hyderabad. Chemicals used were sodium carbonate, sodium hydroxide, hydrochloric acid as buffer for $\mathrm{pH}$ adjustments. The effluent was analyzed using XRF, and the composition is given in Table 1. It had a pH of 0.4 , TDS of 0 and turbidity of 0.64 .

\subsection{Adsorbent preparation}

Sweet lime peel was washed several times with deionized water and dried first in sunlight and then in a hot air oven at $90^{\circ} \mathrm{C}$ till they became crisp. The dry peel was then ground into fine powder and sieved through a $425-\mu$ sieve. This powder was washed with deionized double distilled water (DDDW) till the washings were color free. After this, the adsorbent was dried in an air oven at $105^{\circ} \mathrm{C}$ till dry 
Table 1 Effluent metal ion composition

\begin{tabular}{lc}
\hline Metal ion & $\begin{array}{l}\text { Concentra- } \\
\text { tion (mg/L) }\end{array}$ \\
\hline $\mathrm{Fe}(\mathrm{II})$ & 931.8 \\
$\mathrm{Ni}(\mathrm{II})$ & 795.2 \\
$\mathrm{Cu}(\mathrm{II})$ & 578.3 \\
$\mathrm{Zn}(\mathrm{II})$ & 70.5 \\
$\mathrm{As}(\mathrm{II})$ & 4.9 \\
$\mathrm{Cd}(\mathrm{II})$ & 34.8 \\
\hline
\end{tabular}

and crushed again [36]. Egg shells were washed with distilled water several times and then air-dried in a hot air oven at $40^{\circ} \mathrm{C}$ for $30 \mathrm{~min}$. They were then ground to powder [28]. Wheat bran was washed with DDDW water and then dried. After drying, wheat bran was ground to powder [31]. Rice bran was collected from a rice mill near Hyderabad. It was prepared for experiments after washing with DDDW water to remove dust and water-soluble impurities and then dried at $105{ }^{\circ} \mathrm{C}$ in an oven for $24 \mathrm{~h}$ and crushed to powder [27]. Sodium-activated bentonite was synthesized by treating $\mathrm{Ca}$ bentonite with $7.5 \%$ sodium carbonate according to Eq. (1). The settled clay was washed several times dried in an oven and stored in airtight bags [37]. Fly ash was dried at $110^{\circ} \mathrm{C}$ for $2 \mathrm{~h}$ in an oven and stored in zip lock bags [30]. All the adsorbents were sieved to different fractions, viz. $>425,425-300,300-150,150-75,<75 \mu$, and stored in zip lock bags for ready use.

$\mathrm{Ca}_{2}^{+}$- bentonite $+\mathrm{Na}_{2} \mathrm{CO}_{3} \rightarrow 2 \mathrm{Na}^{+}$- bentonite $+\mathrm{CaCO}_{3}$

\subsection{Experimental setup and procedure}

\subsubsection{Initial screening}

Experiments were carried out with six different adsorbents, i.e., sweet lime peel, wheat bran, rice bran, fly ash, egg shells and Ca bentonite, in batch adsorption method. The experimental conditions used are listed in Table 2. The basis for choosing the best adsorbents is the percent removal of different metals from solution.

\subsubsection{Characterization of adsorbents}

The surface functional groups on the adsorbents were identified using Fourier transform infrared spectrometer Jasco FT/IR-4200 type A model in the wavenumber range of $4000-400 \mathrm{~cm}^{-1}$ after preparing $\mathrm{KBr}$ pellets. The specific surface areas of the adsorbents were measured by BET method. The degassing temperature and time were $150^{\circ} \mathrm{C}$ and $3 \mathrm{~h}$, respectively, for all samples.

\subsubsection{Adsorbent blends}

To further enhance the metal removal efficiency, the three best adsorbents were used to make blends of different compositions CB-WB-FA as 33.3-33.3-33.3, 40-40-20, 20-20-60, 20-60-20, 20-40-40, 40-20-40, 60-20-20. Batch adsorption experiments were done with these blends with process conditions, viz. dosage as $1 \mathrm{~g} / 50 \mathrm{ml}$ solution, temperature of $30^{\circ} \mathrm{C}$, pH of 5.5 , contact time $90 \mathrm{~min}$, particle size 300-150 $\mu$ and $200 \mathrm{rpm}$ agitation speed. The blend which gave maximum metal removal considering all metals was selected for further studies.

\subsubsection{Process conditions to study effect of process parameters}

Different process parameters, viz. contact time, $\mathrm{pH}$, particle size, agitation speed, dosage and temperature, were considered for adsorption studies in metal removal. To study the effect of each of these parameters on adsorption, experiments were done with conditions listed in Table 3.

\subsubsection{Estimation of adsorption capacity}

The amount of metal ions adsorbed was calculated by the difference in initial and final concentration of metal ions. The percentage removal $(\% R)$ was calculated using the following equation:

$\% R=\frac{C_{0}-C_{t}}{C_{0}} \times 100$

Table 2 Process conditions for adsorbents in the initial screening

\begin{tabular}{|c|c|c|c|c|c|c|}
\hline Parameters $(\downarrow)$ /adsorbents $(\rightarrow)$ & Sweet lime & Egg shell & Wheat bran & Rice bran & Fly ash & Ca bentonite \\
\hline $\mathrm{pH}$ & 5 & 6 & 5 & 2 & 4 & 7 \\
\hline $\operatorname{Temp}\left({ }^{\circ} \mathrm{C}\right)$ & 25 & 25 & 25 & 25 & 25 & 25 \\
\hline Agitation speed (rpm) & 200 & 200 & 150 & 200 & 200 & 200 \\
\hline Dosage (g/100 mL) & 0.2 & 1 & 2 & 2 & 2 & 0.5 \\
\hline Contact time (h) & 3 & 1.5 & 1 & 1.5 & 1.5 & 1 \\
\hline Particle size $(\mu)$ & $150-300$ & $300-450$ & $150-300$ & $150-300$ & $150-300$ & $150-300$ \\
\hline
\end{tabular}


Table 3 Process conditions used in experiments for each parameter studied

\begin{tabular}{|c|c|c|c|c|c|c|}
\hline $\begin{array}{l}\text { Parameters studied }(\downarrow) \\
\text { /process parameters } \\
(\rightarrow)\end{array}$ & Contact time (min) & $\mathrm{pH}$ & Particle size $(\mu \mathrm{s})$ & $\begin{array}{l}\text { Agitation speed } \\
(\mathrm{rpm})\end{array}$ & $\begin{array}{l}\text { Dosage } \\
(\mathrm{g} / 50 \mathrm{ml})\end{array}$ & $\begin{array}{l}\text { Temperature } \\
\left({ }^{\circ} \mathrm{C}\right)\end{array}$ \\
\hline Contact time & $2,5,10,15,30,40,60,90,120$ & 5.5 & $300-150$ & 200 & 1 & 30 \\
\hline $\mathrm{pH}$ & 90 & $2,3.8,5.5,7$ & $300-150$ & 200 & 1 & 30 \\
\hline Particle size & 90 & 5.5 & $\begin{array}{r}600-425,425-300 \\
300-150,150-75\end{array}$ & 200 & 1 & 30 \\
\hline Agitation speed & 90 & 5.5 & $300-150$ & $100,150,200,250$ & 1 & 30 \\
\hline Dosage & 90 & 5.5 & $300-150$ & 200 & $0.2,0.5,0.7,1$ & 30 \\
\hline Temperature & 90 & 5.5 & $300-150$ & 200 & 1 & $20,30,40,50$ \\
\hline
\end{tabular}

And the adsorption capacity $\left(q_{t}\right)$ was calculated using Eq. 3.

$q_{t}=\frac{\left(C_{0}-C_{t}\right) V}{m}$

where $C_{0}$ is the initial concentration of metal ion (mg/L), $C_{t}$ is the concentration of metal ion at time $t(\mathrm{mg} / \mathrm{L}), C_{e}$ is the concentration of metal ion at equilibrium $(\mathrm{mg} / \mathrm{L}), \mathrm{m}$ is the mass of adsorbent $(\mathrm{g}), V$ is the volume of solution $(\mathrm{L})$ and $q_{t}$ is the adsorption capacity at time $t(\mathrm{mg} / \mathrm{g})$.

\section{Results and discussion}

\subsection{Initial screening}

The adsorbents selected for initial screening, viz. sweet lime peel, egg shells, wheat bran, rice bran, fly ash and calcium bentonite, were used in a batch adsorption method for the metal removal (Table 2). Figure 1 shows the performance analysis of these adsorbents in terms of percent removal of different metals from effluent. From the results, it is obvious that wheat bran (WB), fly ash (FA) and calcium bentonite $(C B)$ exhibited better removal of heavy metals for most metals, and hence, these three adsorbents were chosen for making blends to achieve enhanced metal removal.

\subsection{Adsorbent composition}

To study the effect of adsorbent blend composition on percentage removal of different metal ions, experiments were done with specifications listed in Table 3. From the results that are depicted in Fig. 2 and Table 4, it is clear that the 33.33-33.33-33.33(CB-WB-FA) and the 60-20-20 blends are the best out of all studied blends. These two blends removed $\mathrm{Zn}$, As, Cd completely after $90 \mathrm{~min}$. The

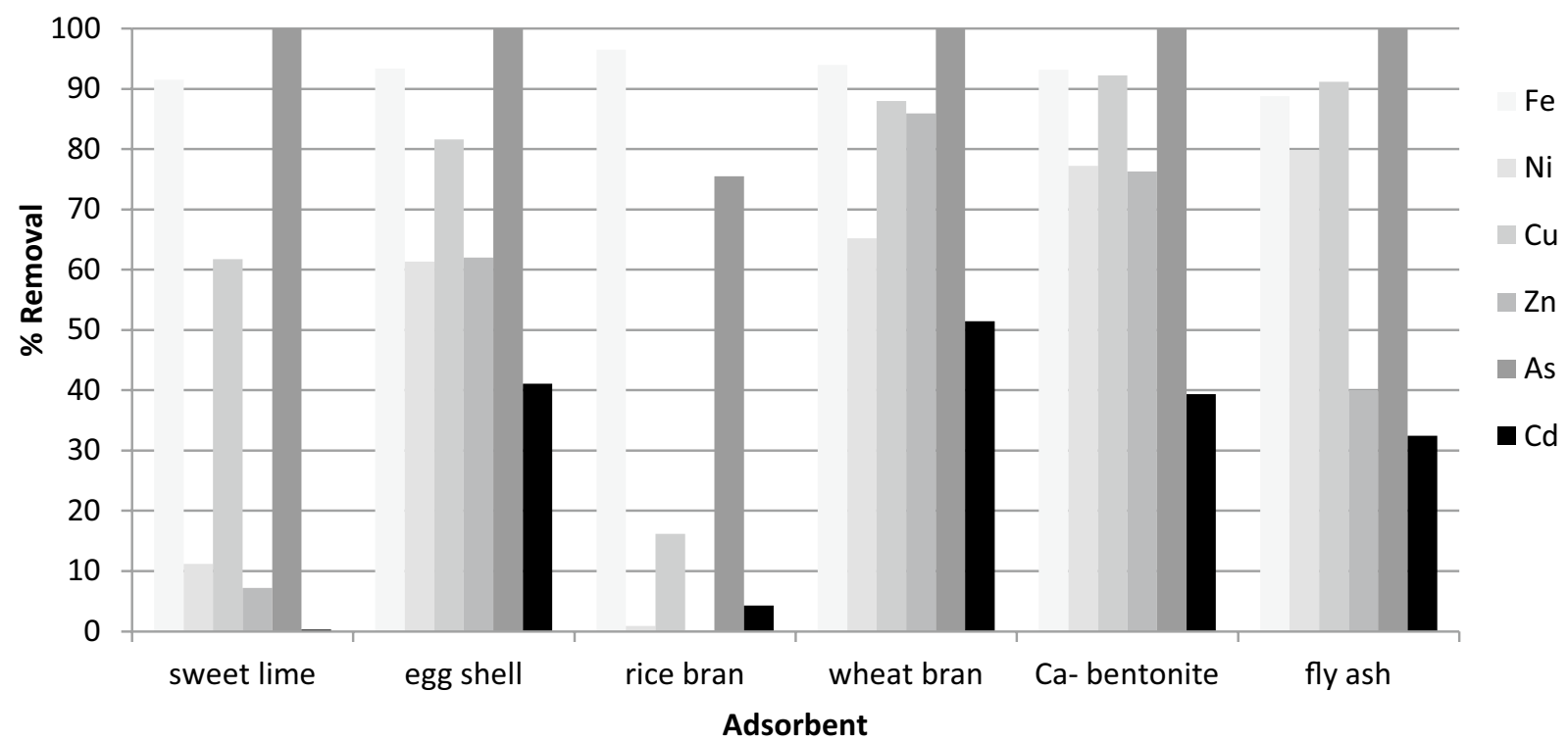

Fig. 1 Percentage removal of metal ions using different adsorbents 


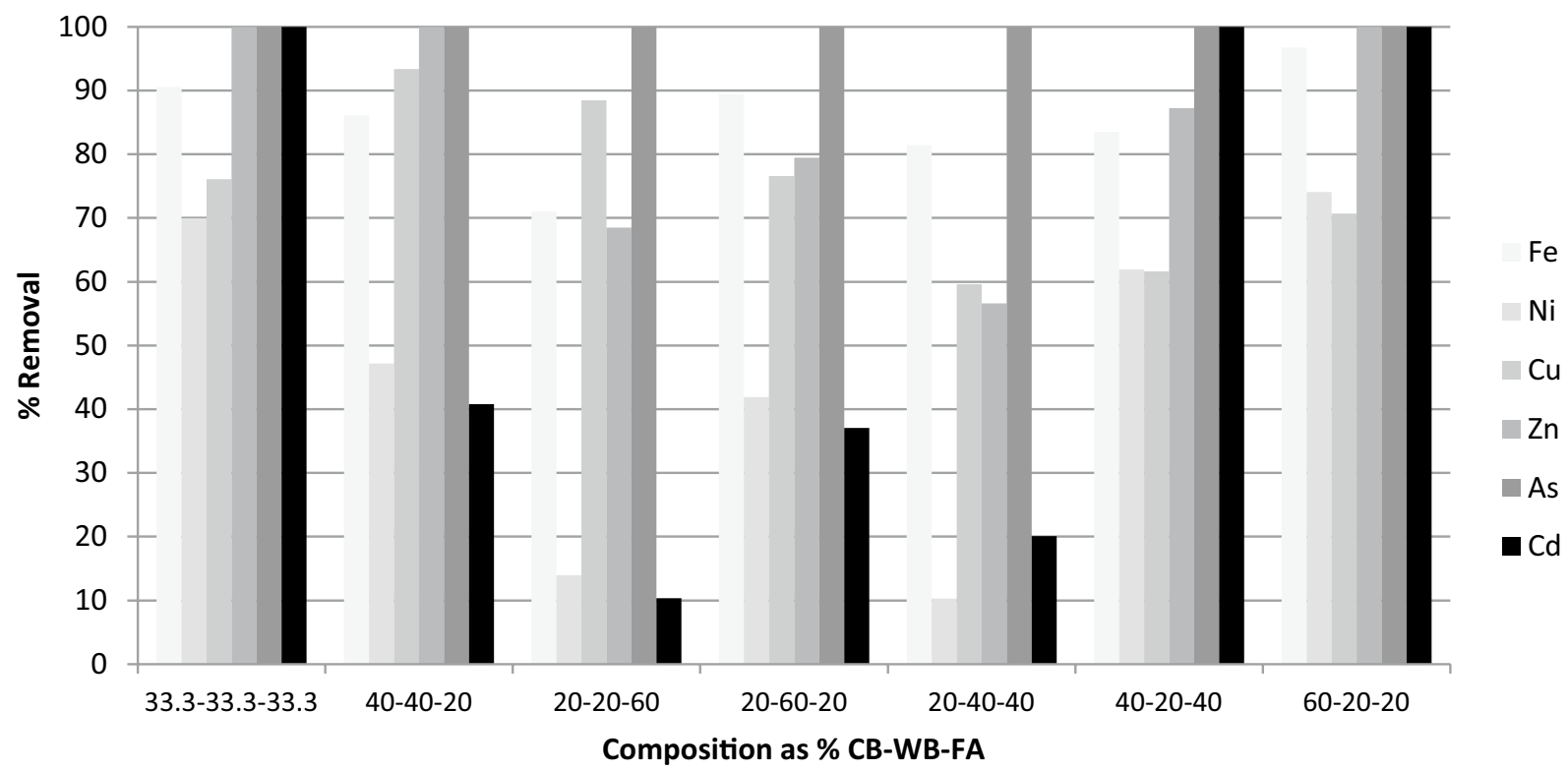

Fig. 2 Percentage removal of metal ions using different adsorbent blend compositions

Table 4 Percent removal of heavy metals using CB-WB-FA in different compositions at specified condition

\begin{tabular}{llllllll}
\hline Metals & $33.3-33.3-33$ & $40-40-20$ & $20-20-60$ & $20-60-20$ & $20-40-40$ & $40-20-40$ & $60-20-20$ \\
\hline Fe(II) & 90.52 & 86.05 & 70.97 & 89.36 & 81.41 & 83.51 & 96.73 \\
$\mathrm{Ni}(\mathrm{II})$ & 69.96 & 47.14 & 13.94 & 41.87 & 10.31 & 61.9 & 74.03 \\
$\mathrm{Cu}(\mathrm{II})$ & 76.11 & 93.35 & 88.48 & 76.6 & 59.58 & 61.6 & 70.70 \\
$\mathrm{Zn}(\mathrm{II})$ & 100 & 100 & 68.51 & 79.43 & 56.59 & 87.23 & 100 \\
$\mathrm{As}(\mathrm{II})$ & 100 & 100 & 100 & 100 & 100 & 100 & 100 \\
$\mathrm{Cd}(\mathrm{II})$ & 100 & 40.80 & 10.34 & 37.06 & 20.11 & 100 & 100 \\
\hline
\end{tabular}

former removed more $\mathrm{Cu}(\mathrm{II})$, while the latter removed more $\mathrm{Fe}(\mathrm{II})$ and $\mathrm{Ni}(\mathrm{II})$. Out of these two, 60-20-20 blend was chosen for further studies as it showed higher removal for $\mathrm{Ni}(\mathrm{II})$ and $\mathrm{Fe}$ (II) ions, which are more in concentration as compared to $\mathrm{Cu}(\mathrm{II})$, thus giving it a higher total adsorption capacity. The optimal results shown in Figs. 1 and 2 were reproduced with very good accuracy within an error of less than $4 \%$.

\subsection{Adsorbent characterization}

The FTIR spectra of the three adsorbents CB, FA and WB are shown in Fig. $3 a-c$, respectively. In Fig. $3 a$, the calcium bentonite spectrum has peaks between 3200 and $3617 \mathrm{~cm}^{-1}$ which are attributed to stretching of lattice $\mathrm{OH}(\mathrm{Si}-\mathrm{OH}, \mathrm{Al}-\mathrm{OH})$ and of the adsorbed water. The presence of silica $\mathrm{O}=\mathrm{Si}=\mathrm{O}$ produces the peak at $1421.3 \mathrm{~cm}^{-1}$. The overtone of bending vibration of water is seen at $1658.5 \mathrm{~cm}^{-1}$. The deep band at $1026.9 \mathrm{~cm}^{-1}$ in the stretching mode region is because of $\mathrm{Si}=\mathrm{O}=\mathrm{Si}$ stretching. Bands at 789.7 and $512 \mathrm{~cm}^{-1}$ in the stretching range are because of $\mathrm{Si}-\mathrm{O}-\mathrm{Al}$ and $\mathrm{Si}-\mathrm{O}-\mathrm{Mg}$ stretching and $\mathrm{Si}-\mathrm{O}$ bending frequencies [37]. In Fig. 3b, the spectra of fly ash are shown. The peak at $3438.5 \mathrm{~cm}^{-1}$ is due to $-\mathrm{OH}$ groups on the surface of fly ash and also due to the stretching vibrations of $-\mathrm{OH}$ in water molecules adsorbed on fly ash. The peak at $2923 \mathrm{~cm}^{-1}$ is due to $\mathrm{C}-\mathrm{H}$ stretching vibration of organic carbon. Peak at $1636 \mathrm{~cm}^{-1}$ is due to aromatic $\mathrm{C}=\mathrm{C}$ stretching of organic carbon. The peak at $1084 \mathrm{~cm}^{-1}$ is due to $\mathrm{Si}-\mathrm{O} / \mathrm{Al}-\mathrm{O}$ stretching vibration, while $459 \mathrm{~cm}^{-1}$ is due to them in plane bending vibration. The peak at $783 \mathrm{~cm}^{-1}$ is due to O-Si-O symmetric stretching. The peak at $553.5 \mathrm{~cm}^{-1}$ is due to octahedral linkage of Si-O-Al. In Fig. 3c, the spectra of wheat bran are shown. The peaks at $3511.7 \mathrm{~cm}^{-1}$ and $3263 \mathrm{~cm}^{-1}$ are due to $-\mathrm{OH}$ stretching and $\mathrm{NH}$ stretching, respectively. The $-\mathrm{OH}$ groups in question may be from adsorbed water, primary and alcohol groups in cellulose and hemicelluloses in bran. The peak at $2926.5 \mathrm{~cm}^{-1}$ is due to $\mathrm{CH}$ stretching of methylene group in polysaccharides in bran [38]. The peak at $2400 \mathrm{~cm}^{-1}$ is because of $\mathrm{CO}_{2}$ in air, the medium in which the IR spectra were taken. 

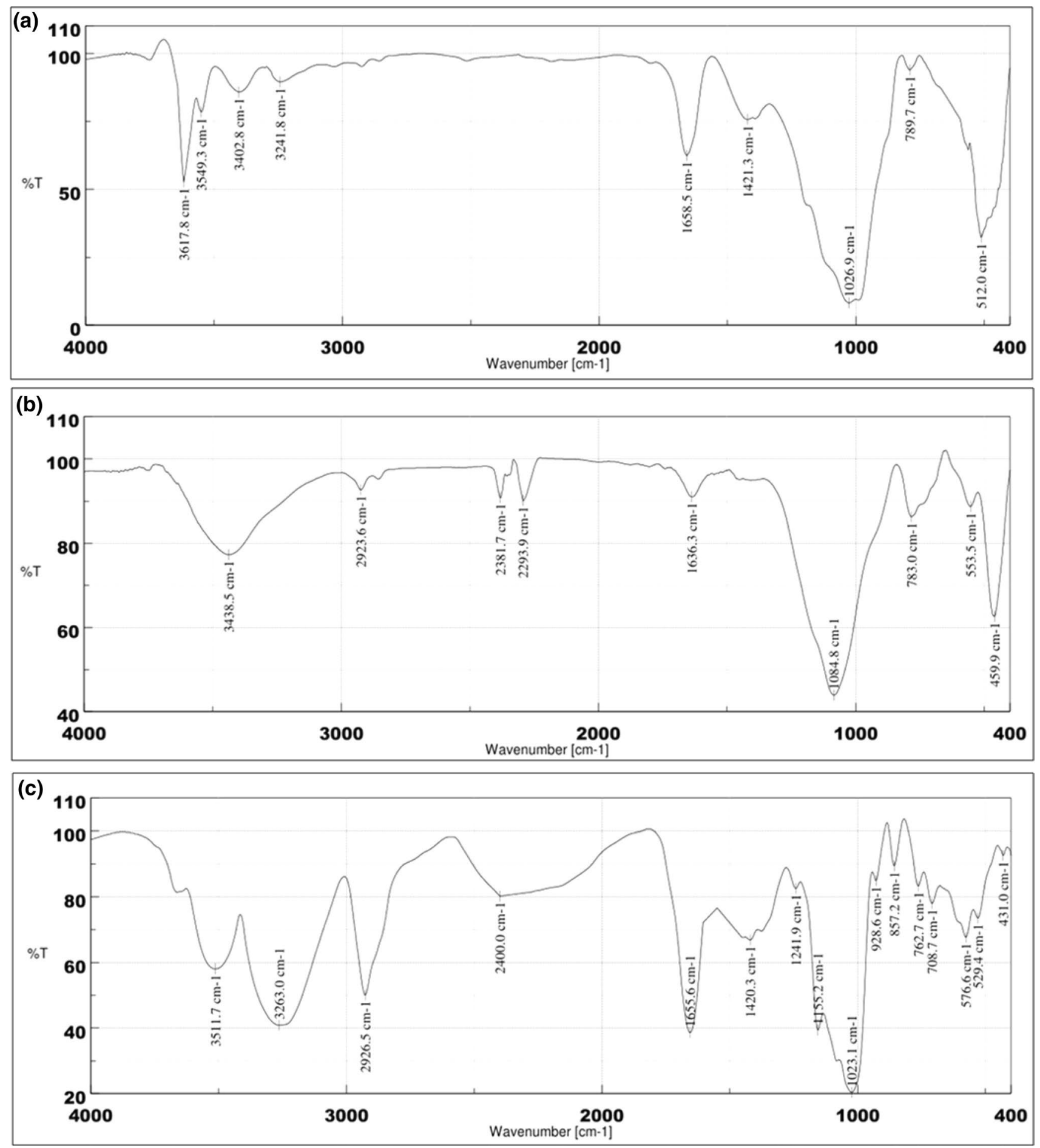

Fig. 3 a FTIR spectra of sodium-activated calcium bentonite, b FTIR spectra of fly ash, c FTIR spectra of wheat bran

The band at $1655.6 \mathrm{~cm}^{-1}$ is due to conjugated $\mathrm{C}=\mathrm{O}$ bond stretching. The peaks at 857.5 and $1420 \mathrm{~cm}^{-1}$ indicate the presence of $\mathrm{CH}_{2}$ groups. The peak at $1155.2 \mathrm{~cm}^{-1}$ is due to aromatic $-\mathrm{OH}$ bond, while the peak at $1241.9 \mathrm{~cm}^{-1}$ is associated with $\mathrm{CH}_{2} \mathrm{OH}$ group present in carbohydrates [39], as well as the $\mathrm{C}-\mathrm{O}-\mathrm{H}$ deformation. The peak at $1023 \mathrm{~cm}^{-1}$ could be because $\mathrm{C}-\mathrm{O}-\mathrm{C}$ group in raw bran [40]. The peak at $928.6 \mathrm{~cm}^{-1}$ is due to out-of-plane blending of $\mathrm{C}-\mathrm{H}$ in cyclohexane [41]. The peak at 762.7 is because of $-\mathrm{C}-\mathrm{H}$ deformation. The band at $708.7 \mathrm{~cm}^{-1}$ is probably because of $=\mathrm{C}-\mathrm{H}$ bending. The peaks at 529.4 and $576.6 \mathrm{~cm}^{-1}$ are probably because of cyclic $\mathrm{C}-\mathrm{H}$ 
out-of-plane deformation. The weak band observed at $431 \mathrm{~cm}^{-1}$ is probably due to $\mathrm{Fe}-\mathrm{O}$ or $\mathrm{Si}-\mathrm{O}$ bends [42]. The BET surface areas of sodium-activated calcium bentonite, fly ash and wheat bran were $95.4 \mathrm{~m}^{2} / \mathrm{g}, 0.4 \mathrm{~m}^{2} \mathrm{~g}$ and $0.3 \mathrm{~m}^{2} \mathrm{~g}$, respectively.

\subsection{Process standardization}

\subsubsection{Effect of contact time}

The effect of contact time on the adsorption of Fe(II), $\mathrm{Ni}(\mathrm{II})$ and $\mathrm{Cu}$ (II) ions from the multi-component solution was studied at various intervals between 1 and $120 \mathrm{~min}$ (Table 3 ). The results are summarized in Fig. $4 a$, and it is clear that the trend is similar for all three ions. It is evident that equilibrium is reached after $90 \mathrm{~min}$ for all three ions, which is relatively fast. The adsorption is fast initially and becomes slower (after $35 \mathrm{~min}$ ) as it attains equilibrium. This can be explained by the availability of fresh/vacant binding sites and external surface area of adsorbent during initial stages, which get exhausted as adsorption proceeds [43]. The free ions in metal solution may also experience some repulsion with adsorbed ions which reduces further adsorption [37]. The percent removal values at equilibrium ( $t=120 \mathrm{~min}$ ) for metals ions $\mathrm{Fe}(\mathrm{II})$, $\mathrm{N}$ (II) and $\mathrm{Cu}(\mathrm{II})$ were found to be $96.93,74.64$ and 70.89, respectively. It has to be noted that segregation of adsorbents due to density differences was not observed in the adsorption vessel. This is attributed to the presence of the magnetic stirrer which improves mixing.

\subsubsection{Effect of $\mathrm{pH}$}

The $\mathrm{pH}$ of aqueous solution is known to be an important variable as it controls the uptake of metal ions at the water-sorbent interface. It directly influences the adsorption capacity and needs to be carefully optimized [18]. For investigating the same, $\mathrm{pH}$ was varied between 2 and 7 (Table 3 ) and $\% R$ values were noted. It was observed that the percent removal increased with increasing $\mathrm{pH}$ for all three ions, as seen in Fig. 4b. At low pH, the lower percent removal is due to excess $\mathrm{H}^{+}$ions surrounding the binding sites and making them positively charged by protonation reaction [31]. This leads to repulsion of the metal ions from the adsorbent which makes adsorption unfavorable. The hydrogen ions also offer competition to the metal ions in
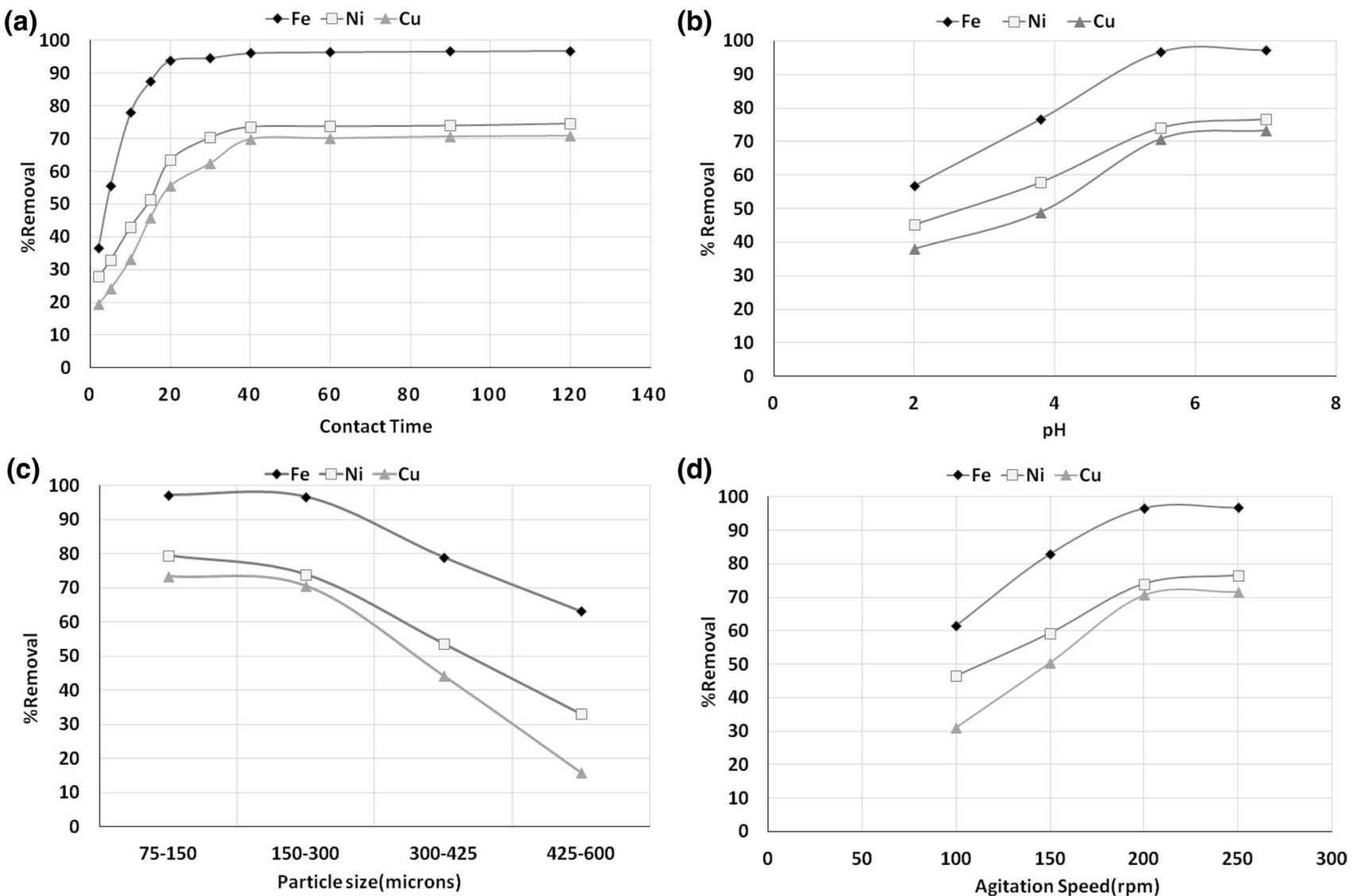

Fig. 4 a Effect of contact time required for percent removal of metal ions, $\mathbf{b}$ effect of $\mathrm{pH}$ on percent removal of metal ions, $\mathbf{c}$ effect of particle size on percent removal of metal ions, $\mathbf{d}$ effect of agitation speed on percent removal of metal ions 
the solution [14]. At high $\mathrm{pH}$, the presence of $\mathrm{OH}^{-}$favors deprotonation reaction which reduces the positive charge density on the adsorbent, favoring adsorption of metal ions [30,37]. For $\mathrm{pH}>7$, the metal ions in the effluent precipitated due to the formation of hydroxides [14], so investigation for basic range of $\mathrm{pH}$ was not done. For all other investigations, a pH of 5.5 was chosen as optimum as it gave higher $\% R$ value and was safely in the acidic region where precipitation of metal hydroxides does not happen.

\subsubsection{Effect of particle size}

Batch adsorption experiments with adsorbent in size ranges of $600-425,425-300,300-150,150-75 \mu$ (Table 3) were used to investigate the effect of particle size. The adsorbent blend was made by taking required weight fractions from appropriate size ranges of each adsorbent. It can be seen from Fig. $4 c$ that the percent removal increases with decreasing particle size. This is because smaller particles have a larger specific surface area, which provide larger number of active sites for the metal ions to bind onto. A particle size of 150-300 $\mu$ was chosen as optimum for use in all experiments.

\subsubsection{Effect of agitation speed}

Agitation of the liquid phase is an important parameter in adsorption phenomena as it influences the mass transfer of metal ions from bulk liquid to surface of the adsorbent. To study the effect of the same, batch adsorption experiments were performed (Table 3) at four different speeds of $100 \mathrm{rpm}$, $150 \mathrm{rpm}, 200 \mathrm{rpm}$ and $250 \mathrm{rpm}$. Results depicted in Fig. 4d show that as the agitation speed was increased, the \% removal of metal ions also increased. This trend was similar for all three ions studied. This is because with the increase in agitation speed the turbulence in liquid phase increases, which increases the external mass transfer coefficients and reduces the boundary layer effect [44]. This leads to faster adsorption as the external resistance decreases. At $200 \mathrm{rpm}$, the percent removal was $\mathrm{Fe}(\mathrm{II})(96.7 \%)>\mathrm{Ni}(\mathrm{II})(74 \%)>\mathrm{Cu}(\mathrm{II})$ (70.7\%). Increasing the agitation speed above $200 \mathrm{rpm}$ did not lead to a significant increase in \% removal, so this was chosen as the optimum value for all other experiments.

\subsubsection{Effect of adsorbent dosage}

The effect of adsorbent dosage was investigated by varying the dose between 0.2 and $1 \mathrm{~g} / 50 \mathrm{ml}$ (Table 3). The results are summarized in Fig. 5a, b. The percent removal increased with the increase in adsorbent dosage for all three ions. This is because at low dosages, the active sites available to the ions were limited, but with more dosage there is more area, and more active sites for the ions to bind to, which increases adsorption percentage. But the adsorption capacity decreased with the increase in dosage Fig. 5b. This is due to two reasons: (1) Increased adsorbent quantity decreases the saturation of active sites. This causes the number of covered sites per unit mass of adsorbent to fall, which leads to a fall in capacity, and (2) increase in concentration of adsorbent in solution causes particle agglomeration which reduces the specific surface area and increases diffusion path length, both of which affect adsorption capacity negatively [45].

\subsubsection{Effect of temperature}

The effect of temperature on adsorption onto the adsorbent blend was investigated at four different temperatures of $20^{\circ} \mathrm{C}, 30^{\circ} \mathrm{C}, 40^{\circ} \mathrm{C}$ and $50{ }^{\circ} \mathrm{C}$ (Table 3). It can be seen from Fig. $5 \mathrm{c}$ that the percent removal of $\mathrm{Fe}$ (II) and $\mathrm{Cu}$ (II) increased with the increase in temperature, indicating that their adsorption onto adsorbents is endothermic $[46,47]$. For $\mathrm{Ni}(\mathrm{II})$ however, the percent removal decreased, indicating exothermic adsorption of $\mathrm{Ni}(\mathrm{II})$ [37].

\subsubsection{Adsorption kinetic models}

For the kinetic study, batch experiments were conducted with conditions: contact time $2-120 \mathrm{~min}$ at $30^{\circ} \mathrm{C}$, $1 \mathrm{~g} / 50 \mathrm{~mL}$ dosage of adsorbent, $\mathrm{pH}$ of 5.5 , agitation speed $200 \mathrm{rpm}$ and particle size of $150-300 \mu$. To identify the suitable kinetic model, kinetic data for the adsorption of Fe(II), $\mathrm{Ni}(\mathrm{II})$ and $\mathrm{Cu}$ (II) ions were analyzed by pseudo-first-order (Eq. 4) and pseudo-second-order (Eq. 5) models where $q_{e}$ is the adsorption capacity at equilibrium, $q_{t}$ is the adsorption capacity at any time $t, k_{1}$ is the rate constant for pseudofirst-order kinetics $\left(\mathrm{min}^{-1}\right)$ and $k_{2}$ is the rate constant of pseudo-second-order kinetics ( $\mathrm{g} / \mathrm{mg} \mathrm{min}$ ).

$\ln \left(q_{e}-q_{t}\right)=\ln q_{e}-k_{1} t$

$\frac{t}{q_{t}}=\frac{1}{k_{2} q_{e}^{2}}+\frac{t}{q_{e}}$

It was found that pseudo-first-order model (plots not shown here) did not fit well for the three metal ions. Pseudo-second-order model $[15,48]$ on the other hand showed good linearity as shown in Fig. 6a. The parameters for the pseudo-second-order model are listed in Table 5. The equilibrium adsorption capacity $\left(q_{e}\right)$ values decreased as $\mathrm{Fe}(\mathrm{II})>\mathrm{Ni}(\mathrm{II})>\mathrm{Cu}(\mathrm{II})$. The experimentally calculated $q_{e}$ and the theoretical $q_{e}$ value were very close to each other. This fact, together with $R^{2}>0.99$, helps us conclude that the pseudo-second-order model describes the system well for all three ions. 

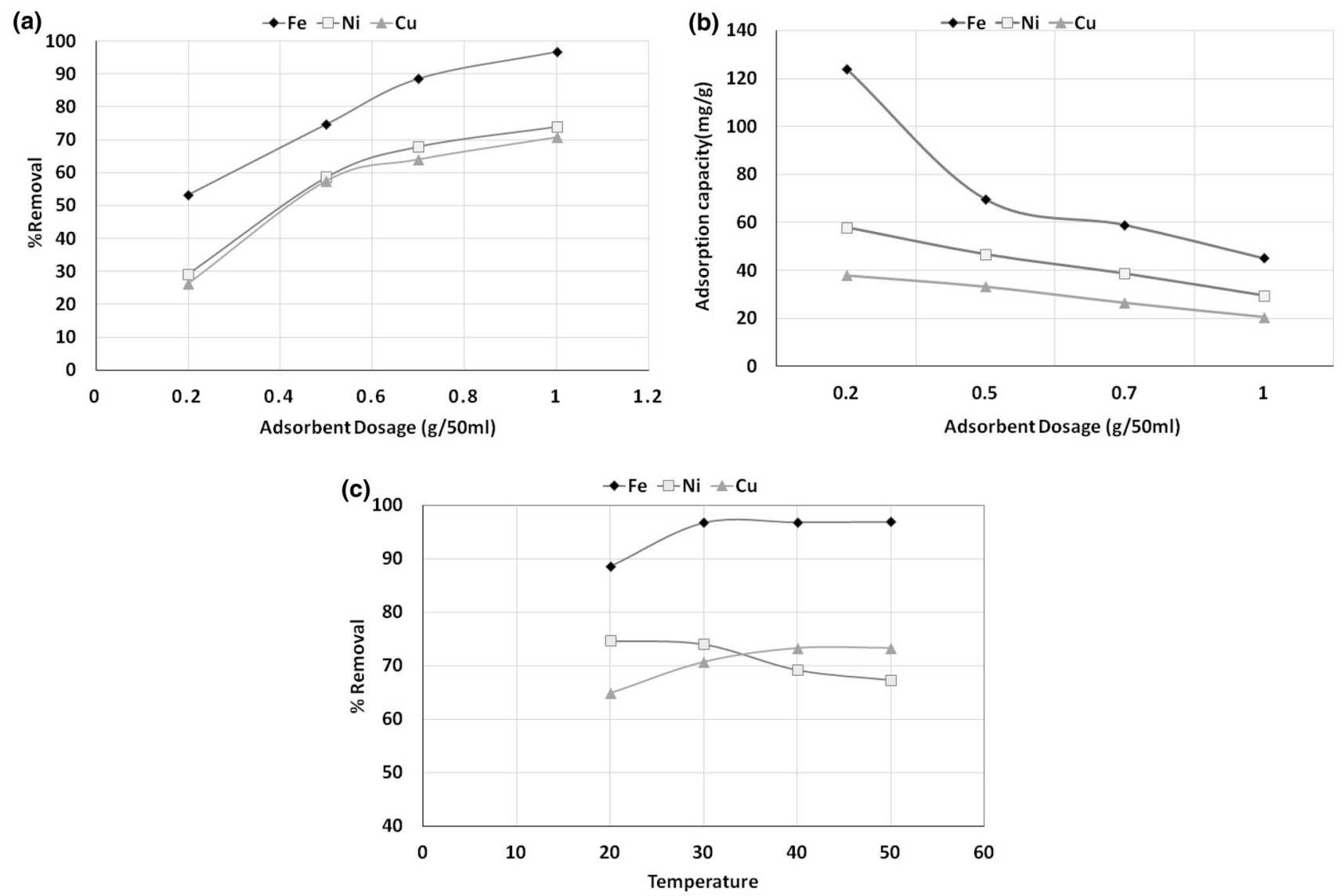

Fig. 5 a Effect of adsorbent dosage on percent removal of metal ions, $\mathbf{b}$ the effect of adsorbent dosage on adsorption capacity $\left(q_{e}\right), \mathbf{c}$ the effect of temperature on percent removal of metal ions

\subsubsection{Intraparticle diffusion model}

The pseudo-second-order kinetic model describes the overall adsorption kinetics satisfactorily, but it gives no information about the rate controlling steps. Adsorption of heavy metal ions onto porous sorbent particles can be described by four consecutive transport steps: (1) transport of ions in the bulk solution; (2) diffusion across the boundary layer around the sorbent particles; (3) diffusion of ions within the pores of the sorbent particles, i.e., intraparticle diffusion; and (4) adsorption of ions on the solid particle surface [49]. In porous adsorbents, intraparticle diffusion is known to play a prominent role, so to investigate the same, kinetic data were analyzed with Weber and Morris intraparticle diffusion model $[48,50]$. According to this model, the adsorption capacity $\left(q_{t}\right)$ is related to time $(t)$ as shown in Eq. 6, where $k_{\text {id }}$ is the intraparticle diffusion rate constant ( $\mathrm{mg} \mathrm{g}^{-1} \cdot \mathrm{min}^{-0.5}$ ) and intercept $C$ is dependent on the effect of diffusion across the liquid boundary layer. Larger the value of $C$, greater the effect of boundary layer diffusion.

$q_{t}=k_{\mathrm{id}} \cdot t^{0.5}+C$
When intraparticle diffusion is the sole rate controlling step, Eq. 6 yields a straight line passing through the origin. A deviation from the origin, quantified by the intercept $C$, indicates some level of control by boundary layer diffusion. Plots of $q_{t}$ versus $t^{0.5}$ for the three metal ions are shown in Fig. 6b. It is apparent that the plot exhibits multi-linearity with three distinct linear regions of different slopes for all three metals. This indicates that in different time intervals, different steps are controlling the overall rate of adsorption. The initial region has the highest slope which is ascribed to the fast adsorption of metal ions onto the exterior surface of fresh adsorbent particles, as it would face only the boundary layer diffusion as ratelimiting step. The second region has a lower slope, i.e., adsorption happens more slowly. This region describes the adsorption rates after all the external sites have been saturated. Now the metal ions have to diffuse through the intraparticle pores to adsorb onto the pore surface area of the particles, and intraparticle diffusion has become the rate-limiting step. This is considerably slower as compared to the first region where boundary layer diffusion (in an agitated liquid) was the rate-limiting step, hence the lower 

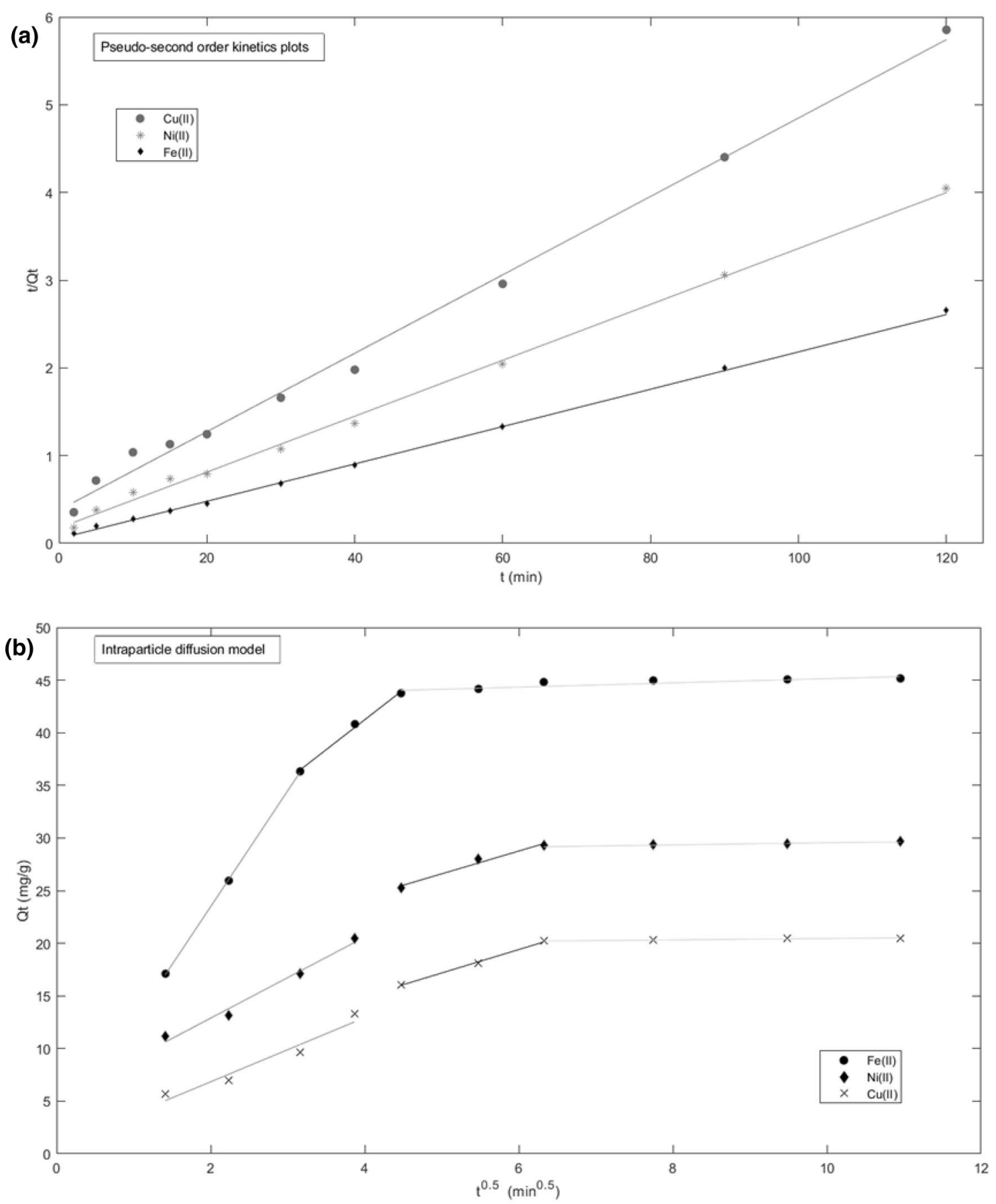

Fig. 6 a Pseudo-second-order kinetics plots for $\mathrm{Fe}(\mathrm{II}), \mathrm{Ni}(\mathrm{II})$ and $\mathrm{Cu}(\mathrm{II})$ ions, b intraparticle diffusion model plots, adsorption capacity versus $t^{0.5}$ for $\mathrm{Fe}(\mathrm{II}), \mathrm{Ni}(\mathrm{II})$ and $\mathrm{Cu}(\mathrm{II})$

slope. In the third region, the adsorption happens at a very low rate, quantified by the almost zero slopes. This is the phase after which almost all the active sites have become saturated and the system has reached equilibrium. Similar multi-linear behavior was reported by other authors [51]. The $k_{\text {id }}$ and $C$ values calculated from each linear region for each metal ion, and the corresponding $R^{2}$ values are summarized in Table 6. As is to be expected, the $k_{\text {id }}$ values followed the order $k_{\mathrm{id} 1}>k_{\mathrm{id} 2}>k_{\mathrm{id} 3}$ for all the metal ions. The multi-linearity of the plot implies that intraparticle diffusion is not the sole rate controlling step for adsorption of the metal ions on the adsorbents in the blend, but it is one of the rate-limiting steps along with boundary layer diffusion. 
Table 5 Pseudo-second-order kinetic parameters for all three metal ions

\begin{tabular}{llllll}
\hline Metal & $C_{o}(\mathrm{mg} / \mathrm{L})$ & $K_{2}$ (g/mg.min) & $\begin{array}{l}q_{e} \text { (cal- } \\
\text { culated) } \\
(\mathrm{mg} / \mathrm{g})\end{array}$ & $\begin{array}{l}q_{e} \text { (experi- } \\
\text { ment) } \\
(\mathrm{mg} / \mathrm{g})\end{array}$ & $R^{2}$ \\
\hline $\mathrm{Fe}(\mathrm{II})$ & 931.8 & 0.00849 & 46.97 & 45.07 & 0.9989 \\
$\mathrm{Ni}(\mathrm{II})$ & 795.2 & 0.00582 & 31.377 & 29.44 & 0.9972 \\
$\mathrm{Cu}(\mathrm{II})$ & 578.3 & 0.00527 & 22.37 & 20.445 & 0.9943 \\
\hline
\end{tabular}

\subsubsection{Adsorption isotherm}

The experimental equilibrium data were collected at conditions with different adsorbent dosages of $0.2,0.5,0.7,1 \mathrm{~g}$ per $50 \mathrm{~mL}$ of effluent with condition of $5.5 \mathrm{pH}$, temperature $303 \mathrm{~K}$, agitation speed $200 \mathrm{rpm}$, particle size $150-300 \mu$ and $90 \mathrm{~min}^{\prime}$ contact time. These data for the adsorption of $\mathrm{Fe}(\mathrm{II}), \mathrm{Ni}(\mathrm{II})$ and $\mathrm{Cu}(\mathrm{II})$ were analyzed with two equilibrium models: Langmuir and Freundlich adsorption isotherms. In linear forms, the Langmuir and Freundlich isotherms are represented by Eqs. 7 and 8, respectively, where $q_{e}$ is the amount of metal adsorbed at equilibrium $(\mathrm{mg} / \mathrm{g}), b$ is the Langmuir constant related to affinity between adsorbate and adsorbent $(\mathrm{L} / \mathrm{mg}), q_{m}$ is the maximum adsorption capacity $(\mathrm{mg} / \mathrm{g}), C_{e}$ is the concentration of metal ions at equilibrium $(\mathrm{mg} / \mathrm{L})$ and $K_{F}$ and $n$ are Freundlich constants and represent adsorption capacity and adsorption intensity, respectively. Langmuir model Eq. (7) assumes that there are a finite number of binding sites on the adsorbent which are homogeneously distributed over its surface and only a single monolayer is formed and there was no interaction between the adsorbed molecules. Once the adsorbent was covered with monolayer, the solute transport does not influence the sorption. Adsorption efficiency can be predicted by a dimensionless constant separation factor or equilibrium parameter $R_{L}$ Eq. (9) where $C_{o}$ is the initial metal concentration $(\mathrm{mg} / \mathrm{L})$ and $b$ is the Langmuir constant $(\mathrm{L} / \mathrm{mg})$. If $R_{L}>1$, then the adsorption is unfavorable; if $R_{L}=1$, then the adsorption is linear; if $0<R_{L}<1$, then the adsorption is favorable; and if $R_{L}=0$, it is irreversible [11].

$\frac{C_{e}}{q_{e}}=\frac{1}{q_{m} b}+\frac{C_{e}}{q_{m}}$

$\log q_{e}=\log K_{F}+\frac{1}{n} \log C_{e}$
$R_{L}=\frac{1}{1+b C_{o}}$

Freundlich isotherm Eq. (8) is an exponential equation which states that the adsorbate concentration on surface of the adsorbent increases as the adsorbate concentration in the solution increases. Freundlich isotherm is an empirical equation which is used for heterogeneous systems. For testing the applicability of these models, linear plots of $\frac{C_{e}}{a_{e}}$ versus $C_{e}$ and $\log \left(q_{e}\right)$ versus $\log C_{e}$ were made. They are shown in Fig. 7a, b, respectively. The $R^{2}$ values indicated that Freundlich isotherm fit the experimental data somewhat better compared to the Langmuir model. The parameters associated with the two models are tabulated in Table 7. For the Freundlich model, the values of $K_{F}$ (order) indicate that the preferential order of adsorption follows $\mathrm{Fe}(\mathrm{II})>\mathrm{Ni}(\mathrm{II})>\mathrm{Cu}(\mathrm{II})$. The values of $n$ are greater than 1 for $\mathrm{Fe}(\mathrm{II}), \mathrm{Ni}(\mathrm{II})$ and $\mathrm{Cu}(\mathrm{II})$ which indicate favorable adsorption onto the blend [48]. From the Langmuir isotherm model, the $q_{m}$ values are in the order $\mathrm{Fe}$ (II) $146.1 \mathrm{mg} / \mathrm{g}>\mathrm{Ni}$ (II) $115.9 \mathrm{mg} / \mathrm{g}>\mathrm{Cu}$ (II) $74.5 \mathrm{mg} / \mathrm{g}$ which are quite high. The high maximum adsorption capacity values prove the effectiveness of blending different adsorbents in treating waste water. The $R_{L}$ values for all three metal ions lie between 0 and 1 , which imply favorable adsorption $[14,15,48]$. It was observed that neither Langmuir nor Freundlich isotherm fit the model perfectly. This is because the adsorbent (blend) being used is heterogeneous, and each adsorbentmetal system follows a different adsorption isotherm, so the net effect cannot be explained by a single Langmuir or Freundlich model $[52,53]$.

\subsubsection{Thermodynamics of adsorption}

The thermodynamic parameter Gibbs free energy change $\left(\Delta G^{\circ}\right)$ can be calculated by Eq. 10

$\Delta G^{\circ}=-\mathrm{RT} \ln K_{d}$

$K_{d}=\frac{q_{e}}{C_{e}}$

where $T$ is the absolute temperature in $\mathrm{K}, R$ is the universal gas constant $(8.314 \mathrm{~J} / \mathrm{mol} \mathrm{K})$ and $K_{d}$ is the thermodynamic distribution coefficient calculated by Eq. $11 . K_{d}$ values
Table 6 Intraparticle diffusion model constants for adsorption metal ions onto adsorbent blend

\begin{tabular}{lllllllllll}
\hline Metal & $C_{0}$ & $k_{\text {id } 1}$ & $C_{1}$ & $R_{1}^{2}$ & $k_{\text {id2 }}$ & $C_{2}$ & $R_{2}^{2}$ & $k_{\text {id } 3}$ & $C_{3}$ & $R_{3}^{2}$ \\
\hline $\mathrm{Fe}(\mathrm{II})$ & 931.8 & 11 & 1.4832 & 1 & 5.685 & 18.495 & 0.995 & 0.2026 & 43.115 & 0.776 \\
$\mathrm{Ni}(\mathrm{II})$ & 795.2 & 3.8491 & 5.1888 & 0.982 & 2.1646 & 15.774 & 0.978 & 0.10279 & 28.521 & 0.907 \\
$\mathrm{Cu}(\mathrm{II})$ & 578.3 & 3.0483 & 0.74183 & 0.948 & 2.2246 & 6.0556 & 0.995 & 0.065298 & 19.798 & 0.976 \\
\hline
\end{tabular}

$C_{o}$ in $\mathrm{mg} \mathrm{L}^{-1}, k_{\text {id }}$ values in $\mathrm{mg} \mathrm{g}^{-1} \cdot \mathrm{min}^{-0.5}$ 

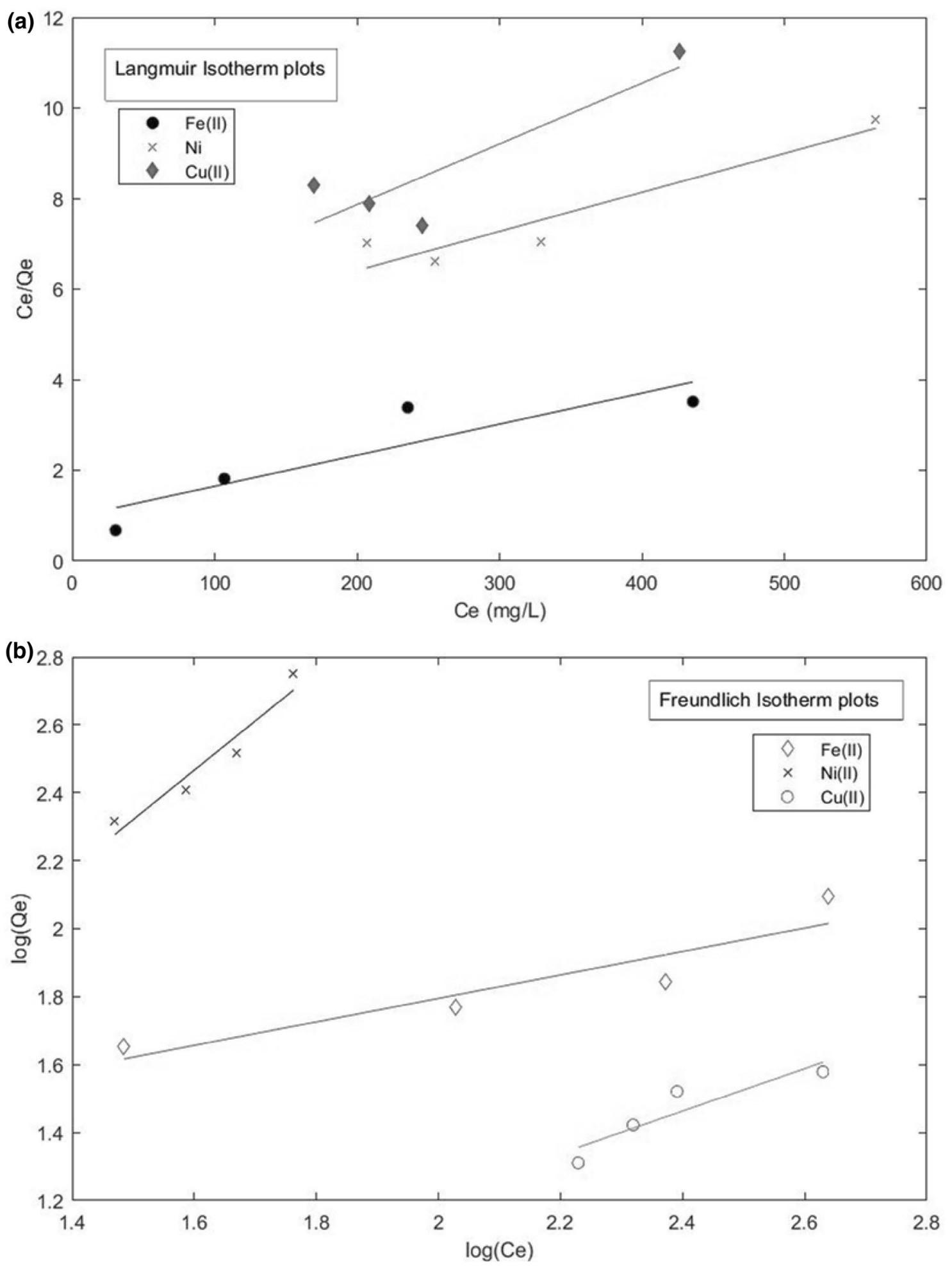

Fig. 7 a Langmuir isotherm plots for adsorption experiments for $\mathrm{Fe}(\mathrm{II}), \mathrm{Ni}(\mathrm{II})$ and $\mathrm{Cu}(\mathrm{II})$ ions and $\mathbf{b}$ Freundlich plots for the adsorption experiments for $\mathrm{Fe}(\mathrm{II}), \mathrm{Ni}(\mathrm{II})$ and $\mathrm{Cu}(\mathrm{II})$ ions

were calculated by the equilibrium values of $q_{e}$ and $C_{e}$ at different temperatures ( $293 \mathrm{~K}, 303 \mathrm{~K}, 313 \mathrm{~K}$ and $323 \mathrm{~K}$ ) while all other parameters were constant $(1 \mathrm{~g}$ per $50 \mathrm{~mL}$ of effluent maintained at $5.5 \mathrm{pH}$, temperature $303 \mathrm{~K}$, agitation speed $200 \mathrm{rpm}$, particle size $150-300 \mu$ and 90 min' $^{\prime}$ contact time). $\Delta G^{\circ}$ values were calculated using Eq. 10 at 
Table 7 Langmuir and Freundlich isotherm constants

\begin{tabular}{|c|c|c|c|c|c|c|c|}
\hline \multirow[t]{2}{*}{ Metal } & \multicolumn{4}{|c|}{ Langmuir isotherm } & \multicolumn{3}{|c|}{ Freundlich isotherm } \\
\hline & $q_{m}(\mathrm{mg} / \mathrm{g})$ & $b(\mathrm{~L} / \mathrm{mg})$ & $R^{2}$ & $R_{L}$ & $K_{F}(\mathrm{mg} / \mathrm{g})$ & $n$ & $R^{2}$ \\
\hline $\mathrm{Fe}(\mathrm{II})$ & 146.1155 & 0.0071 & 0.801 & 0.131 & 3.0198 & 2.8997 & 0.854 \\
\hline $\mathrm{Ni}(\mathrm{II})$ & 115.9541 & 0.0018 & 0.898 & 0.411 & 1.0325 & 1.5711 & 0.925 \\
\hline $\mathrm{Cu}(\mathrm{II})$ & 74.5045 & 0.0026 & 0.779 & 0.400 & 0.96118 & 1.5970 & 0.831 \\
\hline
\end{tabular}

Table 8 Thermodynamic parameters for $\mathrm{Fe}(\mathrm{II}), \mathrm{Ni}(\mathrm{II})$ and $\mathrm{Cu}(\mathrm{II})$ ions

\begin{tabular}{llll}
\hline Metal & Temperature $(\mathrm{K})$ & $K_{d}(\mathrm{mg} / \mathrm{L})$ & $\Delta G^{\circ}(\mathrm{KJ} / \mathrm{mol})$ \\
\hline $\mathrm{Fe}$ & 293 & 0.3874 & 2.309 \\
& 303 & 1.4823 & -0.991 \\
& 313 & 1.5238 & -1.096 \\
$\mathrm{Ni}$ & 323 & 1.5618 & -1.197 \\
& 293 & 0.1475 & 4.662 \\
& 303 & 0.1424 & 4.909 \\
$\mathrm{Cu}$ & 313 & 0.1122 & 5.692 \\
& 323 & 0.1027 & 6.110 \\
& 293 & 0.092 & 5.809 \\
& 303 & 0.120 & 5.326 \\
& 313 & 0.1375 & 5.165 \\
& 323 & 0.1375 & 5.328 \\
\hline
\end{tabular}

different temperatures. The calculated values are listed in Table 8. The negative value of $\Delta G^{\circ}$ for Fe(II) at $303 \mathrm{~K}, 313 \mathrm{~K}$ and $323 \mathrm{~K}$ shows that the adsorption process is feasible and spontaneous at these temperatures [18], but at $293 \mathrm{~K}$ the $\Delta G^{\circ}$ value was positive indicating non-spontaneous adsorption. For $\mathrm{Ni}(\mathrm{II})$ and $\mathrm{Cu}(\mathrm{II})$, the $\Delta G^{\circ}$ values were found to be positive at all temperatures investigated, indicating non-spontaneous adsorption. For Fe(II), the free energy decreased (became more negative) with increasing temperature, i.e., adsorption became more spontaneous. For $\mathrm{Ni}(\mathrm{II})$, the free energy became more positive with increasing temperature, indicating decreasing spontaneity with increasing temperature. For $\mathrm{Cu}(\mathrm{II})$, the spontaneity increased with increasing temperature.

\section{Conclusion}

In the present study, the metal ions of $\mathrm{Fe}(\mathrm{II}), \mathrm{Cu}$ (II) and $\mathrm{Ni}(\mathrm{II})$ besides many others like $\mathrm{Zn}(\mathrm{II}), \mathrm{As}(\mathrm{II}), \mathrm{Cd}(\mathrm{II})$ were removed from an industrial effluent using various adsorbents from industrial and agricultural wastes. After the initial screening of the candidates, three best ones in terms of percent metal removal, viz. calcium bentonite, wheat bran and fly ash, were selected, and then, their possible blends were tried that could give the maximum metal removal under similar conditions. These three adsorbents were characterized with FTIR for identifying the functional groups and BET analysis to measure their specific surface areas. The best adsorbent composition which gave maximum metal removal for the effluent was 60-20-20 wt\% of calcium bentonite-fly ash-wheat bran. Various process parameters, viz. contact time, $\mathrm{pH}$, sorbent dosage, agitation speed and particle size, were found to affect the adsorption of metals $\mathrm{Fe}(\mathrm{II}), \mathrm{Cu}(\mathrm{II})$ and $\mathrm{Ni}(\mathrm{II})$ onto the adsorbent blend. These parameters were standardized rigorously to have the highest possible metal removal. The optimal set of conditions identified were $\mathrm{pH}, 5-7$; contact time, $60-90 \mathrm{~min}$; agitation speed of $200 \mathrm{rpm}$; adsorbent dosage of $1 \mathrm{~g} / 50 \mathrm{~mL}$; and particle size of 150-300 $\mu$. Kinetic studies were done at the optimal conditions to estimate the kinetic parameters, using pseudo-first- and pseudo-second-order models. It was found that pseudo-second-order model could fit the data better that the pseudo-first-order model for all three metal ions. The kinetic constants were found to be $8.49 * 10^{-3}, 5.82 * 10^{-3}, 5.27 * 10^{-3} \frac{\mathrm{g}}{\mathrm{mg} \mathrm{min}}$ for $\mathrm{Fe}(\mathrm{II}), \mathrm{Ni}(\mathrm{II})$ and $\mathrm{Cu}(\mathrm{II})$, respectively. Weber and Morris intraparticle diffusion model was used to analyze the kinetic data, and it was found that there are multiple rate-limiting steps during the adsorption process, including intraparticle diffusion. The equilibrium data were analyzed using Langmuir and Freundlich isotherm models. The maximum Langmuir adsorption capacity values of the three metals for the adsorbent blend were $\mathrm{Fe}(\mathrm{II})$ $146.1 \mathrm{mg} / \mathrm{g}>\mathrm{Ni}$ (II) $115.9 \mathrm{mg} / \mathrm{g}>\mathrm{Cu}$ (II) $74.5 \mathrm{mg} / \mathrm{g}$. It was observed that neither Langmuir nor Freundlich models fit the experimental data satisfactorily. This is observed because the adsorbent used was heterogeneous (blend of three adsorbents), and each component shows different isotherm behaviors. The thermodynamic feasibility and spontaneity of the adsorption process were studied by estimating the Gibbs free energy for each metal ion. For Ni (II) and Cu (II), the adsorption was found to be non-spontaneous at all temperatures studied. For Fe(II), the adsorption was spontaneous at all temperatures studied, except at $293 \mathrm{~K}$. This work demonstrated the successful use of adsorbent blends to treat wastewater containing multiple heavy metals.

Acknowledgements The authors wish to thank HBL Power Systems Ltd., Hyderabad, for providing the effluent needed for our experimental studies. We also thank Ms. Megha Gupta for her contribution in this work. 


\section{Compliance with ethical standards}

Conflict of interest We, the authors declare that there is no conflict of interest in this work.

\section{References}

1. Ghorai S, Sarkar AK, Pal S (2014) Rapid adsorptive removal of toxic $\mathrm{Pb}^{2+}$ ion from aqueous solution using recyclable, biodegradable nanocomposite derived from templated partially hydrolyzed xanthan gum and nanosilica. Bioresour Technol 170:578-582. https://doi.org/10.1016/j.biortech.2014.08.010

2. Sousa FW, Oliveira AG, Ribeiro JP, Rosa MF, Keukeleire D, Nascimento RF (2010) Green coconut shells applied as adsorbent for removal of toxic metal ions using fixed-bed column technology. J Environ Manag 91:1634-1640. https://doi.org/10.1016/j.jenvm an.2010.02.011

3. Tunali S, Çabuk A, Akar T (2006) Removal of lead and copper ions from aqueous solutions by bacterial strain isolated from soil. Chem Eng J 115:203-211. https://doi.org/10.1016/j. cej.2005.09.023

4. Wang LK, Vaccari DA, Li Y, Shammas NK (2005) Chemical precipitation. In: Wang LK, Hung Y-T, Shammas NK (eds) Physicochemical treatment processes. Humana Press, Totowa, pp 141-197. https://doi.org/10.1385/1-59259-820-x:141

5. Juang RS, Shiau RC (2000) Metal removal from aqueous solutions using chitosan-enhanced membrane filtration. J Membr Sci 165:159-167. https://doi.org/10.1016/S0376-7388(99)00235-5

6. Tzanetakis N, Taama WM, Scott K, Jachuck RJJ, Slade RS, Varcoe J (2003) Comparative performance of ion exchange membranes for electrodialysis of nickel and cobalt. Sep PurifTechnol 30:113127. https://doi.org/10.1016/S1383-5866(02)00139-9

7. Barakat MA, Chen YT, Huang CP (2004) Removal of toxic cyanide and $\mathrm{Cu}(\mathrm{II})$ lons from water by illuminated $\mathrm{TiO}_{2}$ catalyst. Appl Catal B 53:13-20. https://doi.org/10.1016/j.apcatb.2004.05.003

8. Al-Qodah Z, Al-Shannag M (2017) Heavy metal ions removal from wastewater using electrocoagulation processes: a comprehensive review. Sep Sci Technol (Phila) 52:2649-2676. https ://doi.org/10.1080/01496395.2017.1373677

9. Barakat MA (2011) New trends in removing heavy metals from industrial wastewater. Arab J Chem 4:361-377. https://doi. org/10.1016/j.arabjc.2010.07.019

10. Naushad M, Ahamad T, AlOthman ZA, Al-Muhtaseb AH (2019) Green and eco-friendly nanocomposite for the removal of toxic $\mathrm{Hg}(\mathrm{II})$ metal ion from aqueous environment: adsorption kinetics \& isotherm modelling. J Mol Liq 279:1-8. https://doi. org/10.1016/j.molliq.2019.01.090

11. Kumar P, Kumar P (2019) Removal of cadmium (Cd-II) from aqueous solution using gas industry-based adsorbent. SN Appl Sci 1:1-8. https://doi.org/10.1007/s42452-019-0377-8

12. AL-Othman ZA, Ali R, Naushad M (2012) Hexavalent chromium removal from aqueous medium by activated carbon prepared from peanut shell: adsorption kinetics, equilibrium and thermodynamic studies. Chem Eng J 184:238-247. https://doi. org/10.1016/j.cej.2012.01.048

13. Naushad M, Vasudevan S, Sharma G, Kumar A, Alothman ZA (2016) Adsorption kinetics, isotherms, and thermodynamic studies for $\mathrm{Hg}^{2+}$ adsorption from aqueous medium using alizarin redS-loaded amberlite IRA-400 resin. Desalin Water Treat 57:1855118559. https://doi.org/10.1080/19443994.2015.1090914

14. Naushad $M$, Ahamad T, Sharma G, Al-Muhtaseb AH, Albadarin AB, Alam MM, ALOthman ZA, Alshehri SM, Ghfar AA (2016)
Synthesis and characterization of a new starch $/ \mathrm{SnO}_{2}$ nanocomposite for efficient adsorption of toxic $\mathrm{Hg}^{2+}$ metal ion. Chem Eng J 300:306-316. https://doi.org/10.1016/j.cej.2016.04.084

15. Alqadami AA, Naushad $M$, Abdalla MA, Ahamad T, ALOthman ZA, Alshehri SM, Ghfar AA (2017) Efficient removal of toxic metal ions from wastewater using a recyclable nanocomposite: a study of adsorption parameters and interaction mechanism. J Clean Prod 156:426-436. https://doi.org/10.1016/j.jclep ro.2017.04.085

16. Alqadami AA, Naushad M, Alothman ZA, Ghfar AA (2017) Novel metal-organic framework (MOF) based composite material for the sequestration of $\mathrm{U}(\mathrm{VI})$ and $\mathrm{Th}(\mathrm{IV})$ metal ions from aqueous environment. ACS Appl Mater Interfaces 9:36026-36037. https ://doi.org/10.1021/acsami.7b10768

17. Alqadami AA, Naushad M, Alothman ZA, Ahamad T (2018) Adsorptive performance of MOF nanocomposite for methylene blue and malachite green dyes: kinetics, isotherm and mechanism. J Environ Manag 223:29-36. https://doi.org/10.1016/j. jenvman.2018.05.090

18. Naushad M, Ahamad T, Al-Maswari BM, Alqadami AA, Alshehri SM (2017) Nickel ferrite bearing nitrogen-doped mesoporous carbon as efficient adsorbent for the removal of highly toxic metal ion from aqueous medium. Chem Eng J 330:1351-1360. https://doi.org/10.1016/j.cej.2017.08.079

19. Naushad M (2014) Surfactant assisted nano-composite cation exchanger: development, characterization and applications for the removal of toxic $\mathrm{Pb}^{2+}$ from aqueous medium. Chem Eng J 235:100-108. https://doi.org/10.1016/j.cej.2013.09.013

20. Gupta VK, Srivastava SK, Mohan D, Sharma S (1998) Design parameters for fixed bed reactors of activated carbon developed from fertilizer waste for the removal of some heavy metal ions. Waste Manag 17:517-522. https://doi.org/10.1016/S0956 -053X(97)10062-9

21. Horsfall M, Abia AA, Spiff Al (2006) Kinetic studies on the adsorption of $\mathrm{Cd}^{2+}, \mathrm{Cu}^{2+}$ and $\mathrm{Zn}^{2+}$ ions from aqueous solutions by cassava (Manihot sculenta Cranz) tuber bark waste. Bioresour Technol 97:283-291. https://doi.org/10.1016/j.biortech.2005.02.016

22. Wang XS, Li ZZ, Tao SR (2009) Removal of chromium (VI) from aqueous solution using walnut hull. J Environ Manag 90:721729. https://doi.org/10.1016/j.jenvman.2008.01.011

23. Zouboulis Al, Loukidou MX, Matis KA (2004) Biosorption of toxic metals from aqueous solutions by bacteria strains isolated from metal-polluted soils. Process Biochem 39:909-916. https://doi. org/10.1016/S0032-9592(03)00200-0

24. Jianlong W (2002) Biosorption of copper(II) by chemically modified biomass of Saccharomyces cerevisiae. Process Biochem 37:847-850. https://doi.org/10.1016/S0032-9592(01)00284-9

25. Chojnacka K, Chojnacki A, Górecka H (2004) Trace element removal by Spirulina sp. from copper smelter and refinery effluents. Hydrometallurgy 73:147-153. https://doi.org/10.1016/j. hydromet.2003.10.003

26. Amarasinghe BMWPK, Williams RA (2007) Tea waste as a low cost adsorbent for the removal of $\mathrm{Cu}$ and $\mathrm{Pb}$ from wastewater. Chem Eng J 132:299-309. https://doi.org/10.1016/j.cej.2007.01.016

27. Singh KK, Rastogi R, Hasan SH (2005) Removal of $\mathrm{Cr}(\mathrm{VI})$ from wastewater using rice bran. J Colloid Interface Sci 290:61-68. https://doi.org/10.1016/j.jcis.2005.04.011

28. Arunlertaree C, Kaewsomboon W, Kumsopa A, Pokethitiyook P, Panyawathanakit P (2007) Removal of lead from battery manufacturing wastewater by egg shell. Songklanakarin J Sci Technol 29:857-868. https://doi.org/10.1016/j.proenv.2012.01.372

29. Oubagaranadin JUK, Sathyamurthy N, Murthy ZVP (2007) Evaluation of Fuller's earth for the adsorption of mercury from aqueous solutions: a comparative study with activated carbon. J Hazard Mater 142:165-174. https://doi.org/10.1016/j.jhazm at.2006.08.001 
30. Sočo E, Kalembkiewicz J (2013) Adsorption of nickel(II) and copper(II) ions from aqueous solution by coal fly ash. J Environ Chem Eng 1:581-588. https://doi.org/10.1016/j.jece.2013.06.029

31. Bulut $Y$, Baysal Z (2006) Removal of Pb(II) from wastewater using wheat bran. J Environ Manag 78:107-113. https://doi. org/10.1016/j.jenvman.2005.03.010

32. Ahmaruzzaman M (2009) Role of fly ash in the removal of organic pollutants from wastewater. Energy Fuels 23:1494-1511. https://doi.org/10.1021/ef8002697

33. An C, Huang G (2012) Stepwise adsorption of phenanthrene at the fly ash-water interface as affected by solution chemistry: experimental and modeling studies. Environ Sci Technol 46:12742-12750. https://doi.org/10.1021/es3035158

34. Jiao F, Wijaya N, Zhang L, Ninomiya Y, Hocking R (2011) Synchrotron-based XANES speciation of chromium in the oxy-fuel fly ash collected from lab-scale drop-tube furnace. Environ Sci Technol 45:6640-6646. https://doi.org/10.1021/es200545e

35. Karnib M, Kabbani A, Holail H, Olama Z (2014) Heavy metals removal using activated carbon, silica and silica activated carbon composite. Energy Proc 50:113-120. https://doi. org/10.1016/j.egypro.2014.06.014

36. Shakoor S, Nasar A (2016) Removal of methylene blue dye from artificially contaminated water using citrus limetta peel waste as a very low cost adsorbent. J Taiwan Inst Chem Eng 0:1-10. https ://doi.org/10.1016/j.jtice.2016.06.009

37. Taha AA, Shreadah MA, Ahmed AM, Heiba HF (2016) Multicomponent adsorption of $\mathrm{Pb}(\mathrm{II}), \mathrm{Cd}(\mathrm{II})$, and $\mathrm{Ni}(\mathrm{II})$ onto Egyptian $\mathrm{Na}$-activated bentonite; equilibrium, kinetics, thermodynamics, and application for seawater desalination. J Environ Chem Eng 4:1166-1180. https://doi.org/10.1016/j.jece.2016.01.025

38. Laque A, Yu S, Rezai-zadeh K, Biomedical P, Rouge B (2016) HHS Public Access 16:77-90. https://doi.org/10.1111/obr.12258 appetite

39. Kizil R, Irudayaraj J, Seetharaman K (2002) Characterization of irradiated starches by using FT-Raman and FTIR spectroscopy. J Agric Food Chem 50:3912-3918. https://doi.org/10.1021/jf011652p

40. Renu M, Agarwal K (2017) Singh, removal of copper, cadmium, and chromium from wastewater by modified wheat bran using Box-Behnken design: kinetics and isotherm. Sep Sci Technol (Phila) 00:1-14. https://doi.org/10.1080/01496395.2017.1417316

41. Mandak E, Zhu D, Godany TA (2013) Fourier transform infrared spectroscopy and Raman spectroscopy as tools for identification of steryl ferulates. J Agric Food Chem 61:2446-2452

42. Singh KK, Singh AK, Hasan SH (2006) Low cost bio-sorbent wheat bran for the removal of cadmium from wastewater: kinetic and equilibrium studies. Bioresour Technol 97:994-1001. https://doi.org/10.1016/j.biortech.2005.04.043

43. Ahamad T, Naushad M, Ruksana SM Alshehri (2019) Ultra-fast spill oil recovery using a mesoporous lignin based nanocomposite prepared from date palm pits (Phoenix dactylifera L.).
Int J Biol Macromol 130:139-147. https://doi.org/10.1016/j.ijbio mac.2019.02.038

44. Geethakarthi A, Phanikumar BR (2011) Adsorption of reactive dyes from aqueous solutions by tannery sludge developed activated carbon: kinetic and equilibrium studies. Int J Environ Sci Technol 8:561-570. https://doi.org/10.1007/BF03326242

45. Vieira MGA, Neto AFA, Gimenes ML, da Silva MGC (2010) Sorption kinetics and equilibrium for the removal of nickel ions from aqueous phase on calcined Bofe bentonite clay. J Hazard Mater 177:362-371. https://doi.org/10.1016/j.jhazmat.2009.12.040

46. Maneechakr P, Karnjanakom S (2017) Adsorption behaviour of $\mathrm{Fe}(\mathrm{II})$ and $\mathrm{Cr}(\mathrm{VI})$ on activated carbon: surface chemistry, isotherm, kinetic and thermodynamic studies. J Chem Thermodyn 106:104-112. https://doi.org/10.1016/j.jct.2016.11.021

47. Sharma G, Kumar A, Naushad M, García-Peñas A, Al-Muhtaseb AH, Ghfar AA, Sharma V, Ahamad T, Stadler FJ (2018) Fabrication and characterization of gum arabic-cl-poly(acrylamide) nanohydrogel for effective adsorption of crystal violet dye. Carbohydr Polym 202:444-453. https://doi.org/10.1016/j.carbp ol.2018.09.004

48. Alshehri SM, Naushad M, Ahamad T, Alothman ZA, Aldalbahi A (2014) Synthesis, characterization of curcumin based ecofriendly antimicrobial bio-adsorbent for the removal of phenol from aqueous medium. Chem Eng J 254:181-189. https://doi. org/10.1016/j.cej.2014.05.100

49. Plazinski W, Rudzinski W (2009) Kinetics of adsorption at solid/ Solution interfaces controlled by intraparticle diffusion: a theoretical analysis. J Phys Chem C 113:12495-12501. https://doi. org/10.1021/jp902914z

50. Weber WJ, Morris JC (1963) Kinetics of adsorption on carbon from solution. J Sanit Eng Div 89:31-60. https://doi. org/10.1080/002689796173345

51. Belessi V, Romanos G, Boukos N, Lambropoulou D, Trapalis C (2009) Removal of reactive red 195 from aqueous solutions by adsorption on the surface of $\mathrm{TiO}_{2}$ nanoparticles. J Hazard Mater 170:836-844. https://doi.org/10.1016/j.jhazmat.2009.05.045

52. Olu-Owolabi BI, Diagboya PN, Adebowale KO (2014) Evaluation of pyrene sorption-desorption on tropical soils. J Environ Manag 137:1-9. https://doi.org/10.1016/j.jenvman.2014.01.048

53. Weber WJ, McGinley PM, Katz LE (1992) A distributed reactivity model for sorption by soils and sediments. 1 . Conceptual basis and equilibrium assessments. Environ Sci Technol 26:19551962. https://doi.org/10.1021/es00034a012

Publisher's Note Springer Nature remains neutral with regard to jurisdictional claims in published maps and institutional affiliations. 